\title{
マグネタイト/PLA ナノファイバーの機械的特性評価
}

田中 和人* 岡田 卓也** 片山 傳生*

\section{Evaluation of Mechanical Properties of Magnetite/PLA Nanofibers}

by

\author{
Kazuto TAnaKa*, Takuya OkadA** and Tsutao KataYama*
}

\begin{abstract}
Hyperthermia has been reported to be an effective cancer treatment, and magnetic nanofibers are expected to be used for it. As a material of the nanofiber for this purpose, poly lactic acid (PLA) and magnetite $\left(\mathrm{Fe}_{3} \mathrm{O}_{4}\right)$ are used. Aligned fabrics and nonwoven fabrics are usually used for evaluation of mechanical properties on nanofibers containing nano-particles. Since their detailed fracture mechanisms have not been clarified yet, mechanical properties of single nanofiber which is the element of these aligned and nonwoven fabrics must be evaluated. In this study, PLA single nanofibers, magnetite/PLA single nanofibers and their aligned and nonwoven fabrics were fabricated by the electrospinning method and their mechanical properties were evaluated by tensile test. Aligned fabrics having the largest distribution of orientation angle from $80^{\circ}$ to $90^{\circ}$ can be fabricated by the rotation speed of the drum collector at more than $2000 \mathrm{rpm}$. By applying oleic acid treatment to the magnetite, which is added to the PLA nanofiber, the formation of clusters and the decrease of tensile strength of the PLA nanofibers is suppressed. In the nonwoven fabric, not only the tensile strength of the single nanofiber but also the bond at the intersection of their nanofibers greatly affects the tensile strength.
\end{abstract}

Key words:

Nanofiber, Poly-lactic acid, Magnetite, Electrospinning, Single nanofiber, Aligned fabric, Nonwoven fabric, Mechanical property, Tensile test

\section{1 緒言}

がんの治療法には，放射線療法，化学療法，外科手術 などが用いられているが，患者に大きな負担となってお り，新たな治療法としてがん細胞が熱に弱いという特徴 を利用した温熱療法の適用が期待されている ${ }^{11}$. 温熱療法 の一つに，磁気ハイパーサーミアを用いたがん部位の発 熱手法がある ${ }^{2}$. 磁気ハイパーサーミアは，磁性ナノ粒子 をがん部位に集積させて交流磁場を負荷することで局所 的にがん部位のみを発熱させる手法である。磁性ナノ粒 子単体でのハンドリングは困難であるため, 磁性ナノ粒 子をナノファイバーに複合させることが考案されており， 磁性ナノ粒子複合ナノファイバーは，がん治療用メッ シュへの適用が期待されている3) 5).

がん治療用メッシュに用いるナノファイバーの素材と しては, 生体への毒性が低く ${ }^{6}$, 生分解性ポリマーである7 ポリ乳酸（PLA）が利用され，磁性ナノ粒子としては，す でに MRI 造影剂として生体一適用されているマグネタイ 卜 $\left(\mathrm{Fe}_{3} \mathrm{O}_{4}\right){ }^{4), 8}$ の使用が多い.

マグネタイトのようなナノ粒子をナノファイバーに複 合させる場合，ナノ粒子は分散媒やマトリックス中で凝 集体を形成しやすく9)，これにより，ナノファイバーの強 度が低くなるという報告もあり ${ }^{10)}$ ，マグネタイトの凝集 体形成を抑制することが重要である。筆者らは，表面処
理剂にオレイン酸を用いることで，マグネタイトの凝集 体形成を抑制することが可能であり，マグネタイト添加 によるナノファイバーの強度低下を抑制できることを報 告している ${ }^{11)}$.

これまでのナノ粒子添加ナノファイバーの機械的特性 評価に関する研究においては，ナノファイバーを一方向 に配向性を持って積層させた配向ナノファイバーシー 卜 (以後配向シートと称する) やナノファイバーに配向 性を持たせずに積層させたランダムナノファイバー不織 布（以後ランダム不織布と称する）の機械的特性評価に 関する報告があり，いずれにおいても複合させるナノ粒 子の添加量が多くなることで低い強度を示すことが報告

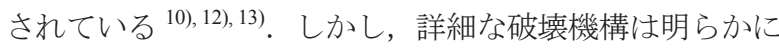
なっておらず，これらを構成するナノファイバー単纎維 の機械的特性も含めて評価をする必要がある.

単繊維の機械的特性評価として，筆者らは，PLA ナ， ファイバー単繊維の引張試験を実現するため，単繊維を 直接紡糸する方法を開発しており ${ }^{14)}$ ，本手法をマグネタ イト複合ナノファイバー単繊維の引張試験に適用するこ とが可能である.

そこで本研究では, PLA ナノファイバー単繊維とマグ ネタイト/PLAナノファイバー単瀻維，およびこれらを用 いた配向シートおよびランダム不織布をエレクトロスピ

$\dagger$ 原稿受理 平成30年1月23日 Received Jan. 23, 2018 @2018 The Society of Materials Science, Japan

* 正 会 員 同志社大学 生命医科学部医工学科 $\bar{\top}$ 610-0394 京田辺市多々羅都谷

Dept. of Biomeded. Eng., Doshisha Univ., Tatara-miyakodani, Kyotanabe, 610-0394.

** 学生会員 同志社大学大学院 T610-0394 京田辺市多々羅都谷

Dept. of Biomeded. Eng., Doshisha Univ., Tatara-miyakodani, Kyotanabe, 610-0394. 
ニング法により紡糸し，引張試験により，マグネタイ

ト/PLAナノファイバーの機械的特性を明らかにした.

\section{2 供試材および実験方法}

\section{$2 \cdot 1$ 供試材}

ポリマー材料として PLA（PLLA，Revode190，浙江海 正生物材料）の樹脂ペレットを用い，PLA を溶解させる ためにジクロロメタン（DCM）を，溶液の導電性を高め るためにジメチルホルムアミド（DMF）を用いた。複合 ナノ粒子にはマグネタイト $\left(\mathrm{Fe}_{3} \mathrm{O}_{4}\right.$, 平均粒子径: $170 \mathrm{~nm}$, 戸田工業）を用い，表面処理にはオレイン酸を用いた.

\section{$2 \cdot 2$ 溶液作製方法}

PLA のポリマー濃度を 10 wt. \%, DCM と DMF の比率 は8:2 とし,マグネタイトの濃度はPLAに対して 10 wt. \%, 20 wt. \%および 30 wt. \%の 3 種類とした. 以後, PLAナノ ファイバーをPLA，それぞれの添加量のマグネタイ ト/PLA ナノファイバーを 10 wt. \% , 20 wt. \%およ び 30 wt. \%と称し, 表面処理を施したマグネタイトを添加 したナノファイバーを Treated，表面処理を施していない マグネタイトを添加したナノファイバーを Untreated と称 する. PLAナノファイバーのポリマー溶液は, 樹脂ペレッ トを DCM 中で撹拌し，スラリー状とした後にDMFを添 加，再度擋汼しポリマー溶液を作製した。マグネタイ 卜/PLAナノファイバーのポリマー溶液は, DCM 中で PLA 樹脂ペレットを擋找したものと DCM 中でマグネタイ ト（Treated の場合は，マグネタイトに対して 14 wt. \%の オレイン酸を添加)を超音波攪拌 $(28 \mathrm{~Hz}$ と $45 \mathrm{~Hz}$ と $100 \mathrm{~Hz}$ の条件下で，各 $3 \mathrm{~min}$ ) したものを混合させ，DMF を添 加後, 再度同一条件の超音波擋汼を施すことで作製した。

\section{$2 \cdot 3$ エレクトロスピニング法によるナノファイバー}

\section{紡系}

ナノファイバーの紡糸にはエレクトロスピニングユ ニット (NANON, MECC) を使用した. 印加電圧を $16 \mathrm{kV}$, 紡系距離 $150 \mathrm{~mm}$, シリンジ送り速度を $1 \mathrm{ml} / \mathrm{h}$ とし, 温度 $25 \pm 3{ }^{\circ} \mathrm{C}$, 湿度 $25 \pm 5 \%$ 環境下でナノファイバーを紡系 した.

単繊維の紡糸には, Fig. 1 に示すように, $20 \mathrm{~mm}$ 離し $3 \mathrm{~V}$ の電位差を与えた銅板 2 枚をターゲットとして用いる方 法を用いた。本方法により，銅板間にブリッジしたナノ ファイバーを創製することが可能である ${ }^{14)}$.

Fig. 2 に模式図を示すドラムコレクタの回転数を $50 \mathrm{rpm}$ として紡糸したものをランダム不織布とし, 回転 数を $1500 \mathrm{rpm}, 2000 \mathrm{rpm}, 2500 \mathrm{rpm}, 3000 \mathrm{rpm}$ の 4 種類で紡 糸したものを配向シートとした．紡糸したナノファイバーは 走査型電子顕微鏡（SEM，JSM-6390LT，日本電子）により観 察し，任意の位置において $18 \mu \mathrm{m} \times 26 \mu \mathrm{m}$ 内に存在するナノ ファイバーがドラムコレクタの回転方向（SEM 観察結果など の上下方向）から傾いている角度から PLA および Treated の 配向度を算出した。 また，SEM 観察画像からナノファイバー 中のマグネタイトの凝集体の大きさ（以後クラスター径と称 する）を測定した。

\section{$2 \cdot 4$ 引張試験}

$2 \cdot 4 \cdot 1$ 単繊維 試験機には, ナノスケール引張試験 機（Nanotensile, Hysitron）を用い, Fig. 3 に示すような, アルミニウムに OHP フィルム（PET，厚さ: $0.1 \mathrm{~mm})$ を 接着したタブに, $2 \cdot 3$ 節で示した方法により銅板間にブ リッジしたナノファイバーを, 導電性テープで固定した ものを試験片とした. 試験直前に, OHP フィルム部分を 切断し単繊維だけに荷重がかかるようにして, 引張変位 速度 $5 \mu \mathrm{m} / \mathrm{s}$ で引張試験を実施した。 なお, 引張強度は, 単繊維の SEM 観察画像から算出した繊維径を用いて断 面が円形であると仮定して算出した.

$2 \cdot 4 \cdot 2$ 配向シート・ランダム不織布 ドラムコレ クタの回転数を $50 \mathrm{rpm}$ として紡糸したランダム不織布,

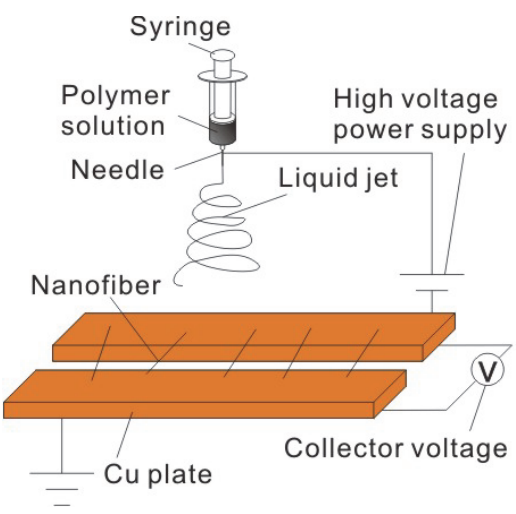

Fig. 1 Schematic drawing of electrospinning process for single nanofibers.

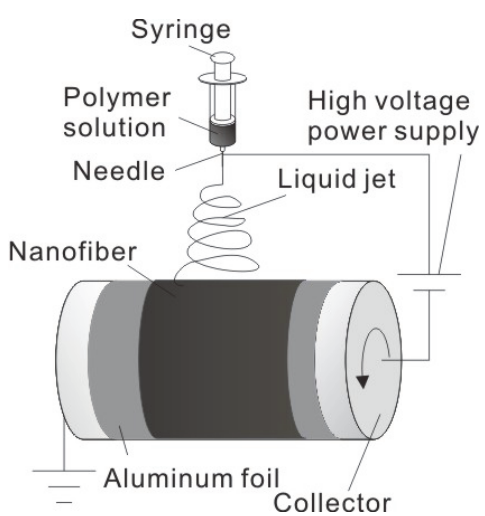

Fig. 2 Schematic drawing of electrospinning process for random and aligned nanofibers.

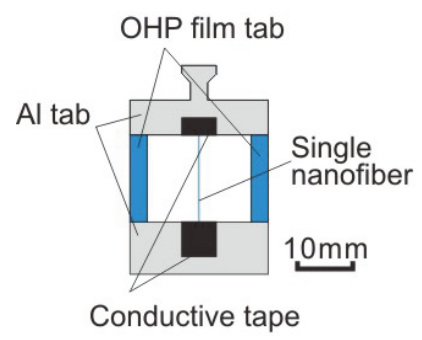

Fig. 3 Schematic drawing of tensile test specimen for a single nanofiber. 
回転数 $2000 \mathrm{rpm}$ で紡系したPLA, TreatedおよびUntreated の 10 wt. \%と 20 wt. \%, さらに回転数 $2500 \mathrm{rpm}$ で紡系し た Treated および Untreated の 30 wt. \%の配向シートを試験 片として用いた．試験片は Fig. 4 (a) に示すようにアルミ ホイル上に紡糸したナノファイバーに OHP フィルムタ ブを貼り付けた後に打抜機でダンベル型に打ち抜き，

OHP フィルムタブで固定して作製した。試験片形状は Fig. 4 (b) に示すような形状となる. 試験機には，小型卓上 試験機（EZ-graph，島津製作所）を用い，荷重容量 $5 \mathrm{~N}$ のロードセルにより荷重を計測し, 引張速 度 $0.017 \mathrm{~mm} / \mathrm{s}(1 \mathrm{~mm} / \mathrm{min})$ の制御下で試験を行った。試 験片を試験機治具に取り付けた後, 試験片の OHP フィ ルムタブを切断し，配向シートやランダム不織布のみに 荷重が負荷されるようにして試験を行った。試験片幅は, ユニバーサルズーム顕微鏡（AZ100, Nikon）を用いて測 定し，平行部 5 か所の平均值を用いた。試験片の実断面 積は断面試料作製装置（CP，SM-09010，日本電子）に より加工した配向シートやランダム不織布の断面を SEM により観察し, ナノファイバーが占める割合を試験

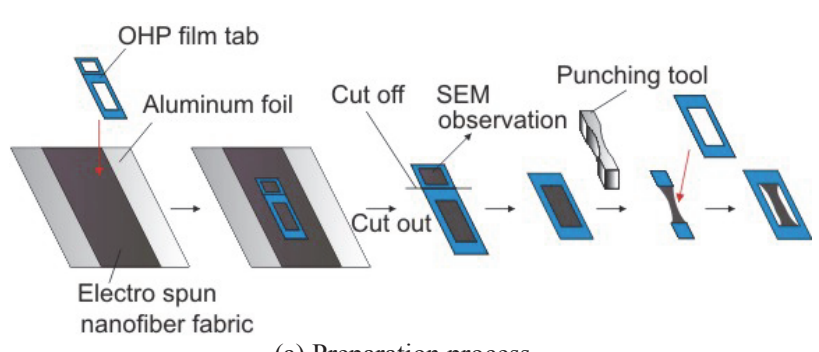

(a) Preparation process

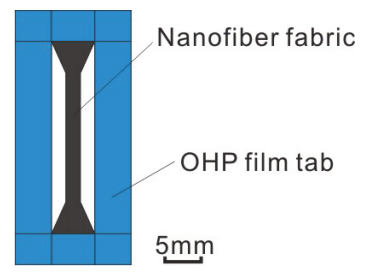

(b) Schematic drawing

Fig. 4 Tensile test specimen for aligned and nonwoven fabrics.

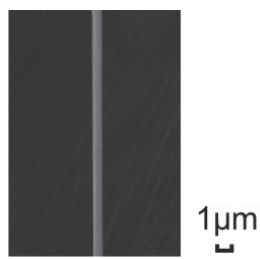

(a) PLA

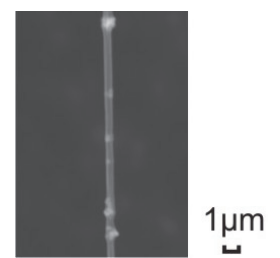

(b) Treated 10 wt. \%

Fig. 5 SEM images of a single nanofiber.
片の外形断面積に乗じることで算出し，この值で荷重を 除すことで公称応力を算出した。

\section{3 実験結果および考察 \\ $3 \cdot 1$ ナノファイバーの形態観察 \\ エレクトロスピニング法によって紡糸した単繊維の} SEM 観察画像の一例を Fig. 5 に示す. Fig. 5 (b) の Treated 10 wt. \%のナノファイバー単繊維において白く観 察できるものがマグネタイトであり，マグネタイトが分 散している複合ナノファイバー単繊維が創製できてい ることがわかる。

Treated 10 wt. \%の配向シートの SEM 観察結果を Fig. 6 に，これらから求めた配向度分布を Fig. 7 に示す. 配向 度の分布の $80^{\circ}$ から $90^{\circ}$ の存在確率が一番高いのは, ド ラムコレクタの回転数が $2000 \mathrm{rpm}$ の時であった. 他のマ グネタイトの添加量においても，80。から $90^{\circ}$ の存在確 率が一番高い回転数をナノファイバーが最も配向する 回転数と定義した．10 wt. \%では，2000 rpm が最も配向 しており，PLA，20 wt. \%においても同様に 2000 rpm が

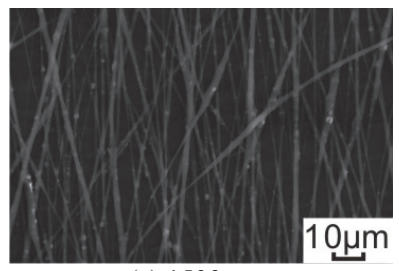

(a) $1500 \mathrm{rpm}$

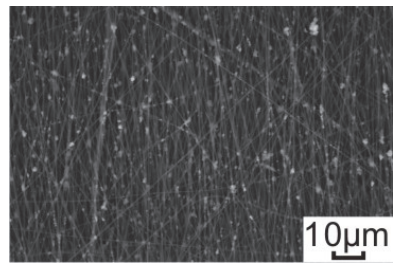

(c) $2500 \mathrm{rpm}$

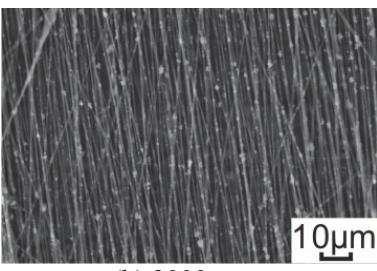

(b) $2000 \mathrm{rpm}$

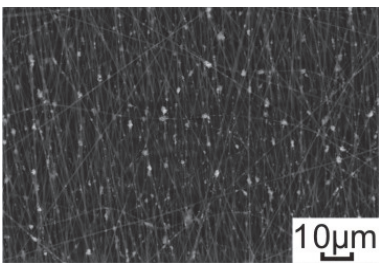

(d) $3000 \mathrm{rpm}$
Fig. 6 SEM images of Treated 10 wt. \% aligned fabric.

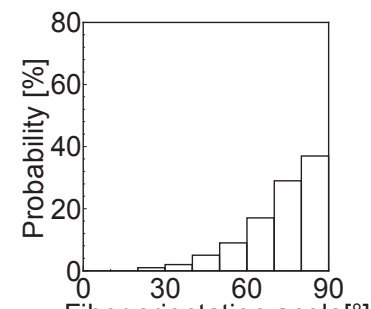

Fiber orientation angle $\left[^{\circ}\right]$

(a) $1500 \mathrm{rpm}$

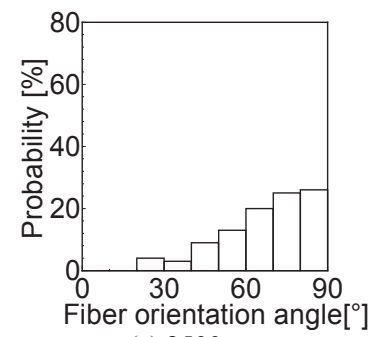

(c) $2500 \mathrm{rpm}$

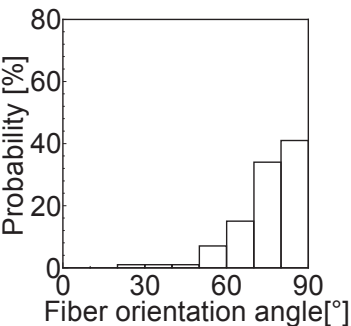

(b) $2000 \mathrm{rpm}$

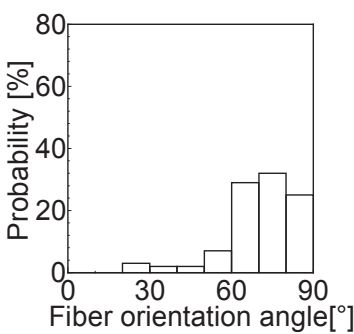

(d) $3000 \mathrm{rpm}$
Fig. 7 Orientation angle of Treated 10 wt. \% aligned fabric. 
最も配向していたのに対して，30 wt. \%の場合だけは, $2500 \mathrm{rpm}$ の時に最も配向した. マグネタイトの添加量が 多くなることにより溶液の粘度が高くなった結果, 大き なテイラーコーンを形成し, 溶液の噴出状態が不安定に なり ${ }^{15)}$ ，高配向度のナノファイバーを紡糸するために は，30 wt. \%においては，PLA，10 wt. \%および 20 wt. \% と比べてより高いドラムコレクタの回転数が必要で あったと考えられる。

PLA と Treated 10 wt. \%, Treated 20 wt. \%, Treated 30wt. \%のランダム不織布の SEM 観察画像を Fig. 8 に,これらおよび各マグネタイト添加量の Untreated の SEM 観察結果（図は省略）から求めたマグ ネタイトのクラスター径分布およびクラスター径の平 均值墂準偏差を Fig. 9 に示す. クラスター径分布にお

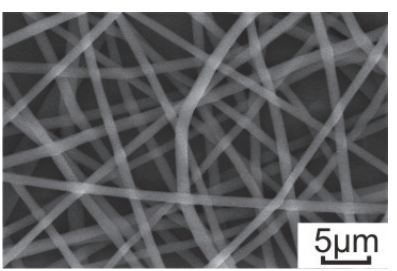

(a) PLA

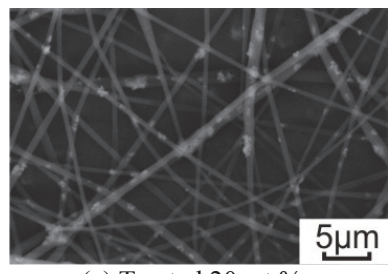

(c) Treated 20 wt. $\%$

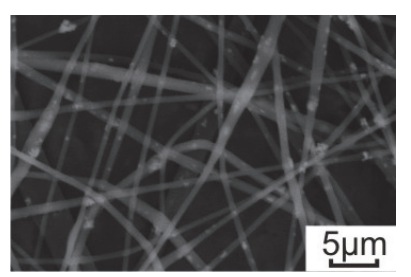

(b) Treated $10 \mathrm{wt} . \%$

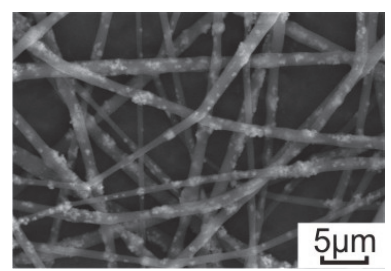

(d) Treated $30 \mathrm{wt.} \%$
Fig. 8 SEM images of nonwoven fabric.

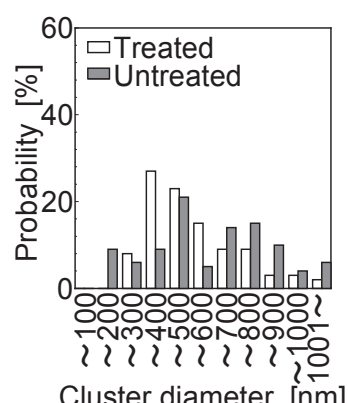

Cluster diameter [nm] (a) 10 wt. $\%$

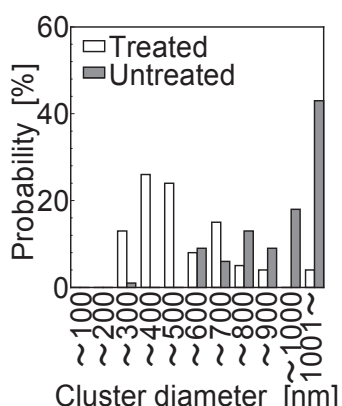

(b) 20 wt. $\%$

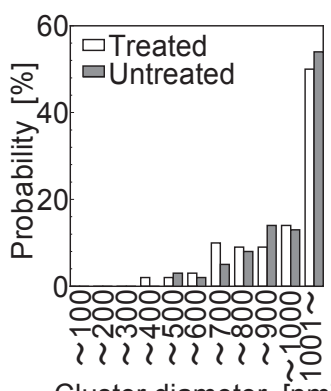

Cluster diameter [nm]

(c) 30 wt. \%

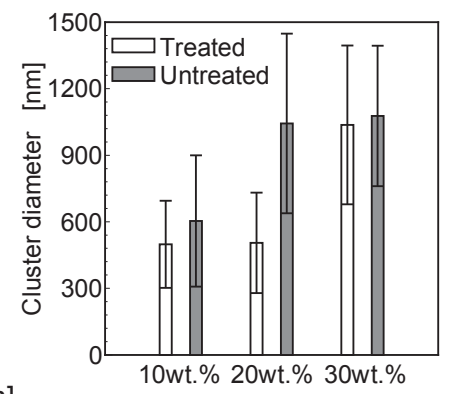

(d) average of cluster diameter $(\mathrm{N}=100$, mean \pm S. D.)
Fig. 9 Distribution of cluster diameter of nonwoven fabrics.
いて， Treated の方が Untreated に比べてクラスター径の 小さいものが多い傾向があり，20 wt. \%においては，ク ラスター径の平均值も大きな違いが見られた。これは, 表面処理剤であるオレイン酸によりマグネタイト表面 ヘカルボキシル基が付与され，これにより粒子間の相互 作用が抑えられクラスターの形成を抑制できたためで あると考えられる ${ }^{16)}$. なお, 結果は省略するが, 配向シー トにおいても同様に, Treated, Untreated ともにマグネタ イトの添加量が多くなるにつれ，クラスター径の大きい 分布が多くなる傾向が見られた.

\section{$3 \cdot 2$ 引張試験}

$3 \cdot 2 \cdot 1$ 単繊維 単繊維引張試験の結果をワイブル 分布として Fig. 10 に，引張強度の平均值標準偏差を Fig. 11 に示す. Treated, Untreated ともに, マグネタイト の添加量が多くなると低い強度を示す傾向が見られた。 Treated 10 wt. \%と Treated 20 wt. \%の平均引張強度はそれ ぞれPLA から $39 \%$, 32\%の低下率であったのに対して, Untreated 10 wt. \%と Untreated 20 wt. \%の強度低下率は $65 \%$ と $69 \%$ となり強度低下率は Treated よりも Untreated の方が大きくなった。これは前節に示したようにマグネ

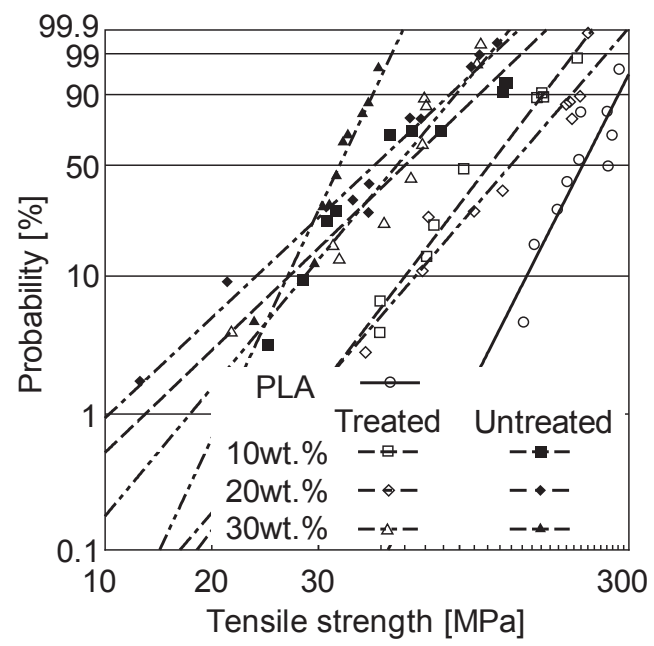

Fig. 10 Weibull plot for tensile strengths of single nanofiber at different contents of magnetite.

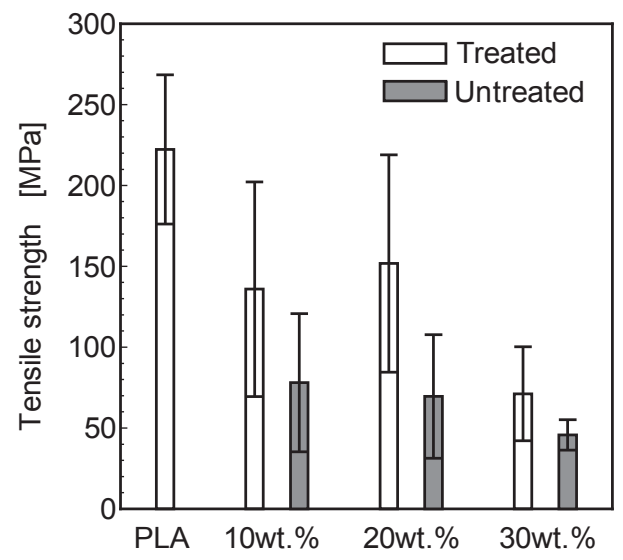

Fig. 11 Tensile strengths of single nanofiber. $(\mathrm{N}=10$, mean \pm S. D. 
タイトにオレイン酸処理を施したことでクラスター形 成を抑制でき，これにより PLA ナノファイバーの強度 低下を抑制できたためであると考えられる，なお，本研 究における引張強度には PLA の結晶化度が影響するこ とも考えられる.PLAの結晶化度については, 添加材が 結晶核剂の役割を果たして結晶化が促進されるという 報告 ${ }^{17)}$ や，逆に結晶化を阻害する役割になるという報 告 ${ }^{18)}$, さらには, 大きな影響は見られない ${ }^{19)}$ という報告 など様々な報告が存在する。今後, マグネタイトの添加 が PLA の結晶化度に及ぼす影響についても検討し, 引 張強度との関係を明らかにすることも重要であると考 えられる。

$3 \cdot 2 \cdot 2$ 配向シート・ランダム不織布 配向シート の引張試験により得られた PLA および Treated の応力変位曲線の一例を Fig. 12 に, PLA 単体, Treated と Untreated すべての配向シートに対する引張強度の平均 值土標準偏差を Fig. 13 に示寸。高い初期勾配を有する領 域で弾性変形した後に, 勾配が大きく変化し緩やかに なっている部分では塑性変形しているものと考えられ る。また，マグネタイトを添加することで破断時の変位 量が PLAよりも小さくなるものの, Treated 10 wt. \%にお

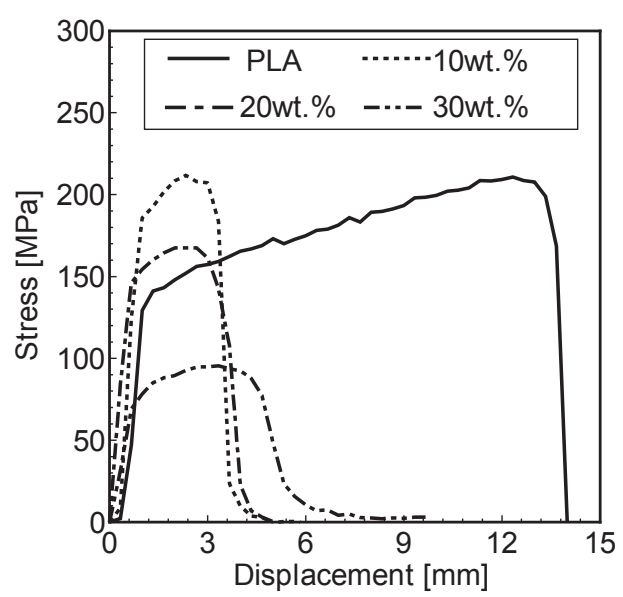

Fig. 12 Stress-displacement curves of PLA and Treated aligned fabric.

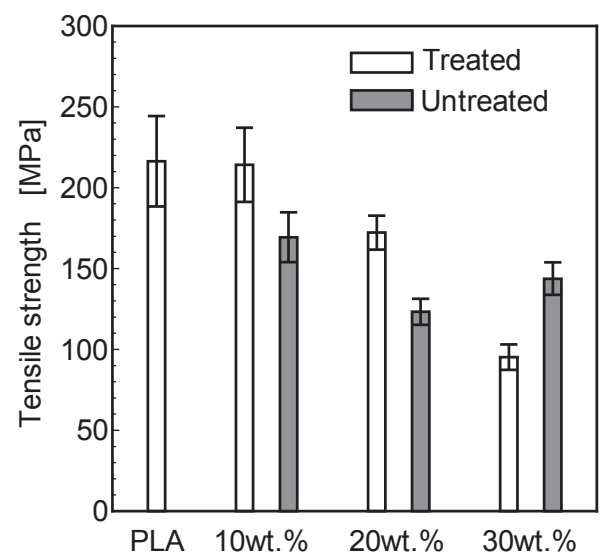

Fig. 13 Tensile strengths of aligned fabric. $(\mathrm{N}=5$, mean \pm S. D.
いては，PLA と同等の強度を示した. Treated, Untreated ともに，マグネタイトの添加量が多くなると低い引張強 度を示し，20 wt. \%の添加量までは Treated の方が Untreated よりも高い強度を示した. 引張試験前後に，ナ ノファイバーの繊維径分布を測定した結果を Fig. 14 に 示寸.引張試験後に繊維径の小さい分布が多くなる傾向 が見られることから, ナノファイバーが引張試験の過程 で塑性変形し, 緎維直径が小さくなっていることがわか る。ランダム不織布の引張試験により得られた Treated 10 wt. \%の応力-変位曲線の一例を Fig. 15 に,

Fig. 15 の応力-変位曲線の上に示した (a)引張試験前, (b) 弾性域内，（c）塑性域内および（d）引張試験後の各点 においてランダム不織布を SEM を用いて観察した結果 を Fig. 16 に示す. 引張試験の過程で, ナノファイバーが 徐々に荷重軸方向に配向していくと同時に繊維径が小 さくなっていることが観察できた。一方，配向せずに曲 線を描いたままのナノファイバーも存在していた。

Fig. 14 に示したように, 配向シートの引張試験において, 引張荷重により塑性変形し緎維径が小さくなっていた. ここで示したランダム不織布においても，ナノファイ

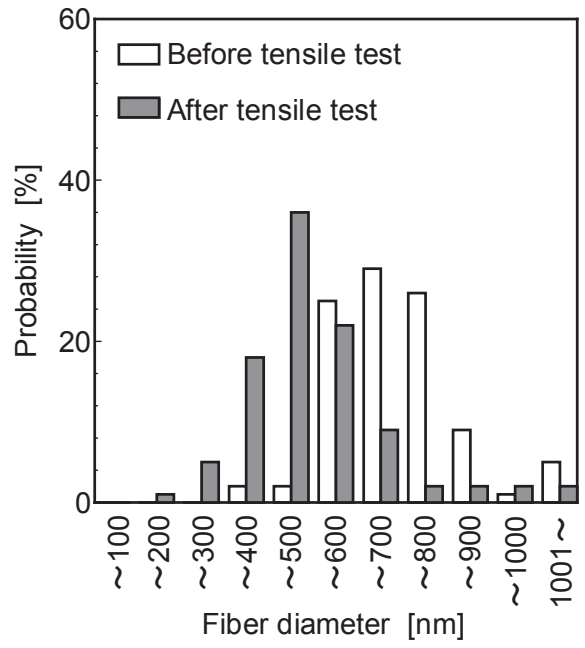

Fig. 14 Distribution of fiber diameter of Treated 10 wt. \% aligned fabric before and after tensile test.

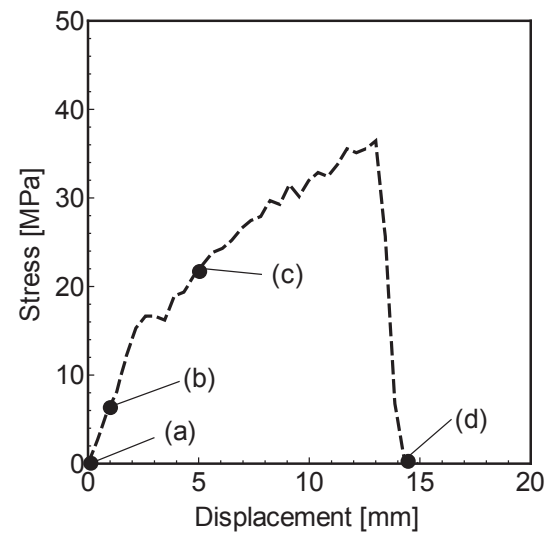

Fig. 15 Stress-displacement curves of Treated $10 \mathrm{wt}$ \% nonwoven fabric. 
バーが引張試験の過程で，荷重軸方向に配向していくと ともに, 塑性変形し, 繊維径が小さくなっていると考え られる。

PLA 単体, Treated, Untreated のすべてのランダム不 織布に対する引張強度の平均值墂準偏差を Fig. 17 に示 す. Treated, Untreated ともに, マグネタイトの添加量が 多くなると低い強度を示し，Treated の方が Untreated よ りも高い強度を示寸傾向が見られた。 また, PLA 単体, Treated, Untreated の寸べての引張強度は, Fig. 13 に示し た配向シートの引張強度と比べると大幅に低い值を示 した. Fig. 4 に示したように，本研究で用いた試験片の ゲージ部は長手方向に長いため, ランダム不織布におい ては，構成するほとんどの単繊維がチャック間でつな がっていない. ランダム不織布においてナノファイバー がランダムに配向していると仮定して，ゲージ長さと試 験片幅からチャック間で連続しているナノファイバー の数を幾何学的に求めるとその割合は $6 \%$ 程度となる. もし仮にこれらのナノファイバーだけが荷重を分担し ている, 寸なわちこれらのナノファイバーの断面積だけ から，相当する単繊維の強度を算出すると，その值は Fig. 11 に示した単繊維の引張強度よりも大幅に高い

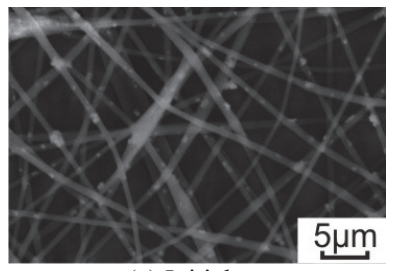

(a) Initial

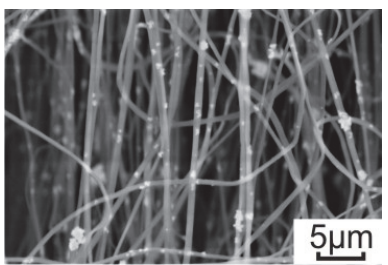

(c) Plastically region

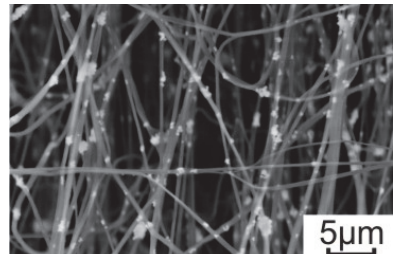

(b) Elastically region

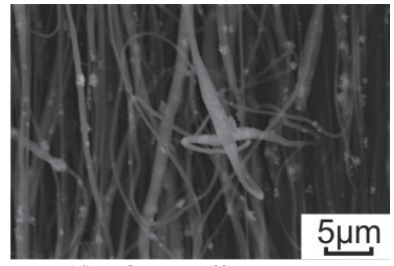

(d) After tensile test
Fig. 16 SEM images of tensile specimen of Treated $10 \mathrm{wt}$ \% observed at each point shown in Fig. 15.

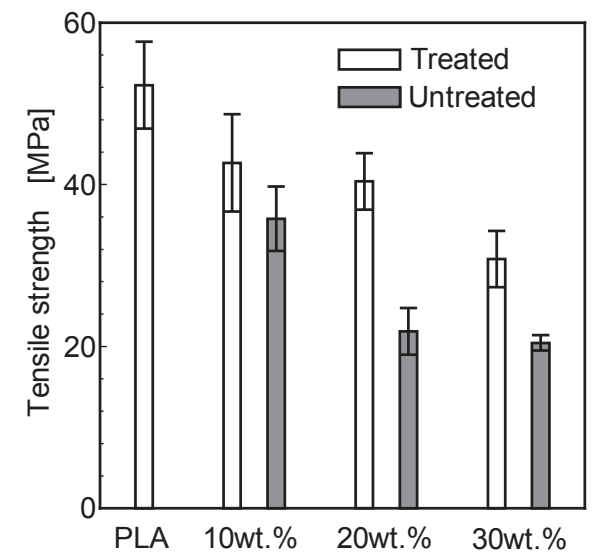

Fig. 17 Tensile strengths of nonwoven fabric. $(\mathrm{N}=5$, mean \pm S. D. $)$
值 $300 \sim 800 \mathrm{MPa}$ を示す. この理由は, PCL のランダム 不織布の引張試験において, 引張試験の過程でナノファ イバー同士の結合による相互作用が荷重を分担するこ とが報告されているため ${ }^{20)}$, 本研究においてもナノファ イバーが複数の交点で他のナノファイバーと結合し，そ のようなナノファイバーが引張試験の過程で荷重を分 担していたと考えられる. ランダム不織布の引張試験に おいては, ナノファイバーが引張試験の過程で, 荷重軸 方向に配向していく過程でこれらの部分が破断し，その 結果, Fig. 16 の SEM 画像に示したような配向せずに曲 線を描いたままのナノファイバーを形成したものと考 えられる。

\section{4 結言}

本研究では, PLA ナノファイバー単繊維とマグネタイ ト/PLA ナノファイバー単繊維, およびこれらを用いた配 向シートおよびランダム不織布をエレクトロスピニング 法により紡糸し，引張試験により，マグネタイト/PLAナ ノファイバーの機械的特性を明らかにした．以下に得ら れた知見を示す.

1. 配向度 80 ○から $90 \circ$ の分布が最も大きい配向シー トは，ドラムコレクタの回転数を $2000 \mathrm{rpm}$ 以上と することで創製できた。 また，マグネタイトの添 加量が多い場合は，高い配向度を有する配向シー トを紡糸するためにはドラムコレクタの回転数を より高くする必要がある.

2. PLA ナノファイバーに添加するマグネタイトにオ レイン酸処理を施すことで, クラスターの形成を 抑制することが可能であり，PLA ナノファイバー の強度低下を抑制することができる.

3. ランダム不織布においては, 単繊維の強度だけで なくナノファイバー同士の交点での結合が強度に 大きく寄与している.

\section{参 考 文 献}

1) J. Beik, Z. Abed, F. S. Ghoreishi, S. Hosseini-nami, S. Mehrzadi, A. Shakeri-zadeh and S. K. Kamrava, "Nanotechnology in hyperthermia cancer therapy: from fundamental principles to advanced applications", Journal of Controlled Release, Vol.235, pp.205-221 (2016).

2) T. C. Lin, F. H. Lin and J. C. Lin, "In vitro feasibility study of the use of a magnetic electrospun chitosan nanofiber composite for hyperthermia treatment of tumor cells", Acta Biomaterialia, Vol.8, No.7, pp.2704-2711 (2012).

3) G. Lv, F. He, X. Wang, F. Gao, G. Zhang, T. Wang, H. Jiang, C. Wu, D. Guo, X. Li, B. Chen and Z. Gu, "Novel nanocomposite of nano $\mathrm{Fe}_{3} \mathrm{O}_{4}$ and polylactide nanofibers for application in drug uptake and induction of cell death of leukemia cancer cells", Langmuir, Vol.24, No.5, pp.2151-2156 (2008).

4) L. Hosseini, K. Mahboobnia and M. Irani, "Fabrication of $\mathrm{PLA} / \mathrm{MWCNT} / \mathrm{Fe}_{3} \mathrm{O}_{4}$ composite nanofibers for leukemia cancer cells", International Journal of 
Polymeric Materials and Polymeric Biomaterials, Vol.65, No.4, pp.176-182 (2016).

5) Y. J. Kim, M. Ebara and T. Aoyagi, "A smart hyperthermia nanofiber with switchable drug release for inducing cancer apoptosis", Advanced Functional Materials, Vol.23, No.46, pp.5753-5761 (2013).

6) R. E. Conn, J. J. Kolstad, J. F. Borzelleca, D. S. Dixler, L. J. Filer Jr, B. N. Ladu Jr and M. W. Pariza, "Safety assessment of polylactide (PLA) for use as a food-contact polymer", Food and Chemical Toxicology, Vol.33, No.4, pp.273-283 (1995).

7) N. Kawashima, "A development of polylactic acid as bio-based polymers", Journal of Synthetic Organic Chemistry, Vol.61, No.5, pp.496-505 (2003).

8) Y. Wu, Y. Wang, G. Luo and Y. Dai, "In situ preparation of magnetic $\mathrm{Fe}_{3} \mathrm{O}_{4}$-chitosan nanoparticles for lipase immobilization by cross-linking and oxidation in aqueous solution”, Bioresource Technology, Vol.100, No.14, pp.3459-3464 (2009).

9) A. Dhawan and V. Sharma, "Toxicity assessment of nanomaterials: methods and challenges", Analytical and Bioanalytical Chemistry, Vol.398, pp.589-605 (2010).

10) R. K. Singh, K. D. Patel, J. H. Lee, E. J. Lee, J. H. Kim, T. H. Kim and H. W. Kim, "Potential of magnetic nanofiber scaffolds with mechanical and biological properties applicable for bone regeneration", Plos One, Vol.9, No.4, e91584 (2014).

11) K. Tanaka, T. Okada, Y. Motohashi and T. Katayama, "Fabrication of magnetite/PLA composite nanofiber sheet and evaluation of its mechanical properties", WIT Transactions on Engineering Sciences, Vol.116, pp.265-272 (2017).

12) S. Shao, S. Zhou, L. Li, J. Li, C. Luo, J. Wang, X. Li and J. Weng, "Osteoblast function on electrically conductive electrospun PLA/MWCNTs nanofibers”, Biomaterials, Vol.32, No.11, pp.2821-2833 (2011)

13) M. Kouhi, M. P. Prabhakaran, M. Shamanian, M. Fathi, M. Morshed and S. Ramakrishna, "Electrospun PHBV nanofibers containing HA and bredigite nanoparticles: fabrication, characterization and evaluation of mechanical properties and bioactivity", Composites Science and Technology, Vol.121, pp.115-122 (2015).

14) K. Tanaka, Y. Minamiguchi and Y. Miyoshi, "Development of an electrospinning method for the tensile testing of single nanofibers", WIT Transactions on the Built Environment, Vol.112, pp.177-184 (2010).

15)J. M. Deitzel, J. Kleinmeyer, D. Harris and N. C. B. Tan, "The effect of processing variables on the morphology of electrospun nanofibers and textiles", Polymer, Vol.42, pp.261-272 (2001).

16) K. Nakatsuka and J. Shimoiizaka, "Preparation of magnetic fluid and its application", The Iron and Steel Institute of Japan, Vol.73, No.1, pp.55-63 (1987).

17) A. M. Harris and E. C. Lee, "Improving mechanical performance of injection molded PLA by controlling crystallinity", Applied Polymer Science, Vol.107, No.4, pp.2246-2255 (2008).

18) G. Y. Liao, X. P. Zhou, L. Chen, X. Y. Zeng, X. L. Xie and Y. W. Mai, "Electrospun aligned PLLA/PCL/functionalised multiwalled carbon nanotube composite fibrous membranes and their bio/mechanical properties", Composites Science and Technology, Vol.72, pp.248-255 (2012).

19) K. Tanaka, T. Shiga and T. Katayama, "Fabrication of Hydroxyapatite/PLA composite nanofibers and effect of surface treatment of hydroxyapatite on their mechanical properties and dispersion", Journal of the Society of Materials Science, Japan, Vol.67, No.2, pp.291-298 (2018).

20) C. D. Gaudio, E. Ercolani, F. Nanni and A. Bianco, "Assessment poly (ع-caprolactone)/poly (3-hydroxybutyrate-co-3-hydr oxyvalerate) blends processed by solvent casting and electrospinning", Materials Science and Engineering A, Vol.528, pp.1764-1772 (2011). 